\title{
Strategi Percepatan Pembangunan Desa Berkembang: Upaya Menuju Desa Mandiri yang Berkelanjutan
}

\author{
Nuri Aliyani* \\ Prodi Ekonomi Pembangunan, Fakultas Ekonomi dan Bisnis, \\ Universitas Islam Bandung, Indonesia. \\ *mynameisnuri31@gmail.com
}

\begin{abstract}
The aim of this study is to determine the strategy for accelerating the development of Developing Villages towards a sustainable Independent Village, through PESTEL-SOAR analysis and case study of Pondok Udik Village. The success of village development in Indonesia is seen from the status of the village through the Village Build Index. Developing Villages are the center of attention because the number of villages included in the Developing Village category is $57.01 \%$ in 2020 , thus requiring accelerated development to become developed and independent villages. The research is use descriptive-qualitative research methods. The types of data consist of primary data obtained through interviews and observations, and secondary data. The results of the study indicate that there is a strategy for accelerating development towards a sustainable Independent Village. The strategies that can be carried out are: first, the S-A strategy that utilizes village strengths to realize the aspirations of all local village communities, focusing on the economic, social, and village infrastructure fields. Second, the S-R strategy, which utilizes the strength of the village to realize the village's vision and mission, focuses on exploiting the potential of the village. Third, the O-A strategy that takes advantage of existing opportunities to realize the aspirations of the village community, focusing on the social sector of the village community and village infrastructure. Fourth, the $\mathrm{O}-\mathrm{R}$ strategy that takes advantage of existing opportunities to realize the village's vision and mission, focusing on sustainable village development.
\end{abstract}

Keywords: Acceleration Strategy, Village Development, Sustainable Rural Development.

\begin{abstract}
Abstrak. Tujuan dari penelitian ini adalah untuk menentukan strategi untuk mempercepat pembangunan desa berkembang menuju sebuah desa independen yang berkelanjutan, melalui analisis PESTEL-melambung dan studi kasus Desa Pondok Udik. Keberhasilan pembangunan desa di Indonesia terlihat dari status desa melalui Indeks Pembangunan Desa. Membangun desa-desa adalah pusat perhatian karena jumlah desa termasuk dalam kategori berkembang Desa adalah $57.01 \%$ pada tahun 2020, sehingga membutuhkan pembangunan menjadi berkembang dan desa independen. Penelitian ini menggunakan metode penelitian deskriptif. Jenis data terdiri dari data primer yang diperoleh melalui wawancara dan pengamatan, dan data sekunder. Hasil penelitian menunjukkan bahwa ada strategi untuk mempercepat pembangunan menuju sebuah desa independen yang berkelanjutan. Strategi yang dapat dilakukan adalah: pertama, strategi yang memanfaatkan kekuatan desa untuk mewujudkan aspirasi komunitas desa, fokus pada ekonomi, sosial, dan bidang infrastruktur desa. Kedua, strategi S-R, yang memanfaatkan kekuatan desa untuk menyadari visi Desa dan misi, berfokus pada mengeksploitasi potensi desa. Ketiga, strategi yang mengambil keuntungan dari kesempatan yang ada untuk mewujudkan aspirasi masyarakat desa, berfokus pada sektor sosial dari komunitas desa dan infrastruktur. Keempat, strategi O-R yang mengambil keuntungan dari peluang yang ada untuk menyadari visi dan Misi Desa, fokus pada pembangunan desa yang berkelanjutan.
\end{abstract}

Kata Kunci: Strategi Percepatan, Pembangunan Desa, Pembangunan Pedesaan Yang Berkelanjutan. 


\section{A. Pendahuluan}

Pembangunan desa dan kawasan perdesaan secara komprehensif merupakan faktor penting bagi pembangunan daerah, pengentasan kemiskinan, dan pengurangan kesenjangan antar wilayah (Budiarto, Rustiadi, \& Dharmawan, 2017). Isu utama pembangunan perdesaan di negara berkembang adalah kemiskinan, mata pencaharian, dan lingkungan (Scoones, 2009). Seperti yang disebutkan Todaro \& Smith (2012), bahwa sumber kemiskinan di negara berkembang berasal dari desa. Menurut Global Food Policy Report (2019), mayoritas orang miskin di dunia tinggal di daerah perdesaan. Tingkat kemiskinan global di daerah perdesaan pada tahun 2019 sebesar 17 persen, dua kali lipat lebih tinggi dari daerah perkotaan, yaitu sebesar 7 persen. Maka dari itu, pentingnya pembangunan perdesaan terutama di negara berkembang.

Krisis telah menunjukkan bahwa strategi pembangunan konvensional pada dasarnya terbatas dan belum memenuhi pembangunan yang adil dan berkelanjutan (Altimir, 1982; Annis \& Hakim, 1988 dalam Altieri \& Masera, 1993). Pembangunan wilayah di perdesaan maupun perkotaan, seharusnya tidak hanya bertumpu pada pencapaian pertumbuhan ekonomi saja, tetapi juga harus berdasarkan pada nilai-nilai pembangunan berkelanjutan dalam segala aspek (Hall \& Pfeiffer, 2000). Pada bulan Juni 1992, diadakan Konferensi Perserikatan Bangsa-Bangsa tentang Lingkungan dan Pembangunan di Rio de Janeiro, dimana telah diakui kebutuhan untuk mengintegrasikan pembangunan ekonomi, dan perlindungan lingkungan ke dalam tujuan pembangunan berkelanjutan (Rusu et al., 2020). Pertumbuhan penduduk yang semakin meningkat, juga menimbulkan dampak negatif terhadap lingkungan. Kebutuhan manusia yang tinggi menjadikan pembangunan tidak memperhatikan kelestarian lingkungan (Nurkholis, 2018). Wilayah perdesaan yang secara ekonomi berkelanjutan dan berkembang secara sosial, menjamin stabilitas, kemandirian, dan ketahanan pangan negara.

Mihai \& Iatu (2020) menegaskan bahwa pembangunan berkelanjutan di daerah perdesaan merupakan sebuah keharusan. Bahkan, pembangunan perdesaan yang berkelanjutan telah ditempatkan pada agenda dunia. Terlepas dari proses migrasi desa-kota, daerah perdesaan terdiri dari wilayah geografis yang luas. Dimana, populasi signifikan masih hidup dan menghadapi ancaman yang muncul terkait dengan perubahan iklim, kemiskinan, dan kurangnya infrastruktur penting, terutama di negara-negara berkembang. Mengurangi kesenjangan geografis dan sosial ekonomi dalam hal kebutuhan dasar, harus menjadi prioritas di tingkat internasional. Di sisi lain, lahan perdesaan memenuhi kebutuhan dasar wilayah perkotaan (bahan mentah, sumber energi, pasokan makanan, air, dan sebagainya), juga permukiman perdesaan berkontribusi pada warisan budaya masing-masing daerah. Oleh karena itu, pembangunan berkelanjutan merupakan masalah yang kompleks (lingkungan-ekonomi-sosial) yang harus ditangani lebih lanjut dengan perhatian yang sama, salah satunya oleh akademisi.

Kesadaran terkait pentingnya pembangunan desa di Indonesia, ditunjukkan dengan lahirnya Undang-Undang Nomor 6 tahun 2014 tentang desa. Kemudian Peraturan Kementerian Desa Nomor 02 tahun 2016 mengenai Indeks Desa Membangun (IDM), yang melihat kemajuan desa dari tiga dimensi ketahanan: sosial, ekonomi, dan lingkungan. IDM mengklasifikasikan desa dalam lima status, yaitu Desa Sangat Tertinggal, Desa Tertinggal, Desa Berkembang, Desa Maju, dan Desa Mandiri. Status desa dijadikan acuan untuk menentukan intervensi baik anggaran maupun kebijakan pembangunan desa, sehingga posisi pembangunan desa dinilai dari status desa tersebut.

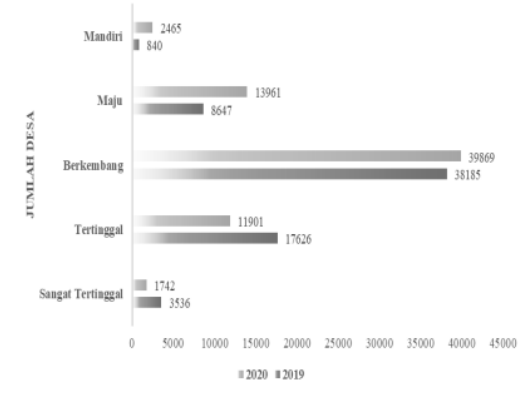

Gambar 1. Status Indeks Desa Membangun Tahun 2019-2020 
Sumber: Kemendesa (2020)

Dalam Bappenas (2019), terdapat sasaran target pembangunan desa tahun 2020-2025, salah satunya yaitu, terwujudnya Desa Berkembang menjadi Desa Mandiri sebanyak 5000 desa. Pada Gambar 1.1 terlihat bahwa Desa Berkembang menduduki posisi tertinggi pada tahun 2019 sebesar 55,47 persen atau 38,185 desa, dan 57,01 persen atau 39,869 desa pada tahun 2020 . Artinya, Desa Berkembang perlu percepatan pembangunan untuk menurunkan angka status desanya menuju Desa Maju dan Desa Mandiri.

Dalam Permendesa Indonesia (2014), Desa Berkembang memiliki potensi sumber daya sosial, ekonomi, dan ekologi, tetapi belum optimal dalam pengelolaannya, sehingga belum mencapai kesejahteraan masyarakat desa, kualitas hidup manusia, dan penanggulangan kemiskinan. Sujito \& Latifah (2020). Di sisi lain, persoalan desa yang belum memiliki profil desa, jumlah warga desa yang miskin, kondisi infrastruktur yang kurang memadai, aparatur desa yang tidak kompeten, dan kantor desa yang tidak layak, menjadi alasan pembangunan yang perlu dipikirkan lebih lanjut (Rahmat, Izzudin, \& Kudir, 2015). Perlunya inovasi, serta adanya kolaborasi dalam pembangunan desa, dapat membantu mempercepat pembangunan desa ke arah yang lebih baik. Desa yang belum mencapai keberhasilan dan kesejahteraan, dapat mencontoh pada desa yang telah berhasil dalam melakukan pembangunan.



Gambar 2. Nilai Indeks Desa Membangun Desa Pondok Udik Tahun 2019-2021

Sumber: Kemendesa (2021)

Salah satu desa yang berhasil melakukan percepatan pembangunan adalah Desa Pondok Udik, yang berada di Kecamatan Kemang, Kabupaten Bogor. Desa Pondok Udik meraih rangking ke lima Peringkat Status IDM desa tahun 2020 dengan perolehan nilai IDM sebesar 0.9740 di tingkat Indonesia, atau peringkat satu di tingkat Jawa Barat (Kemendesa, 2020). Sebelumnya, pada tahun 2019 Desa Pondok Udik merupakan Desa Berkembang dengan nilai IDM sebesar 0.6855 (Kemendesa, 2020). Artinya, hanya dalam kurun waktu satu tahun, desa tersebut mampu meningkatkan statusnya menjadi Desa Mandiri. Desa Pondok Udik juga menjadi salah satu desa yang sangat direkomendasikan oleh Kemendesa untuk ditiru keberhasilan kemandirian desanya. Desa Pondok Udik telah memanfaatkan baik itu sumber daya manusia, dan sumber daya modalnya untuk meningkatkan pembangunan desanya. Pemerintah Desa Pondok Udik selalu berusaha untuk memenuhi dan memaksimalkan program yang telah dirancang oleh desa, maupun yang direkomendasikan oleh Kemendesa. Programprogram yang telah dilakukan oleh desa mampu merubah dan meningkatkan status desanya ke arah yang lebih baik, dengan pencapaian tertinggi yaitu menjadi Desa Mandiri. Dari fakta tersebut, Desa Pondok Udik telah membuktikan bahwa permasalahan pembangunan Desa Berkembang mampu diatasi dengan cepat.

Berdasarkan penjabaran latar belakang yang telah diuraikan, maka perumusan masalah dalam penelitian ini adalah: "Rumusan strategi yang seperti apa, supaya Desa Berkembang dapat mempercepat pembangunan desanya menjadi Desa Mandiri yang berkelanjutan?". Selanjutnya, tujuan dalam penelitian ini diuraikan dalam pokok-pokok berikut:

1. Faktor politik, ekonomi, sosial, ekologi, teknologi, dan hukum yang berpengaruh dan menjadi peluang pada pembangunan desa.

2. Kekuatan (Strength) dan peluang (Opportunities) yang ada di Desa Pondok Udik

3. Aspirasi (Aspiration) dan hasil (Results) yang diinginkan oleh Desa Pondok Udik. 
4. Strategi percepatan pembangunan Desa Berkembang menuju Desa Mandiri yang berkelanjutan.

\section{B. Metodologi Penelitian}

Penelitian ini menggunakan jenis metode studi kasus, dengan pendekatan deskriptif-kualitatif. Pengambilan sampel menggunakan Teknik purposive sampling yang diperoleh dari Desa Pondok Udik, yakni satu dari pemerintah desa, dan tiga dari masyarakat desa. Adapun Teknik pengumpulan data yang digunakan yaitu kepustakaan dan lapangan (wawancara, observasi, dan dokumentasi). Kemudian data tersebut dianalisis menggunakan metode analisis PESTELSOAR.

\section{Hasil Penelitian dan Pembahasan}

\section{Hasil Analisis PESTEL}

Analisis PESTEL diperoleh berdasarkan hasil wawancara dan data sekunder yang diperoleh, dan menganalisis apakah data sekunder tersebut termasuk ke dalam peluang pembangunan desa. Analisis PESTEL juga menjadi pengukur Indikator variabel dari pendekatan pentagon yang dikemukakan oleh Akgün et al. (2011). Dengan mengidentifikasi dan mengevaluasi faktor kritis yang mendukung pembangunan berkelanjutan di Desa Pondok Udik. Analisis PESTEL dari masing-masing faktor adalah sebagai berikut.

\section{Faktor Politik}

Hasil penelitian menunjukkan bahwa pemerintah Indonesia mendukung pembangunan pedesaan dan berkomitmen kuat untuk melaksanakan pembangunan desa skala besar. Komitmen ini ditunjukkan dengan terbitnya Undang-Undang Nomor 6 Tahun 2014 tentang Desa. Selain itu, semua desa juga menjadi program prioritas pemerintah Indonesia. Hal ini tercermin dalam RPJMN tahun 2020-2025. Tentunya hal ini berdampak positif bagi kewenangan dan fungsi desa. Sejak dikeluarkannya komitmen ini, desa-desa di seluruh Indonesia memiliki kewenangan dan fungsi masing-masing untuk mengelola desanya masingmasing. Dana pengelolaan juga diberikan langsung oleh pemerintah Indonesia. Faktor lainnya dapat dilihat pada Tabel 1.

Tabel 1. Faktor Politik, Efek, dan Peluang Pembangunan Desa Berkelanjutan

\section{Faktor Politik}

1. Peraturan terkait pembangunan desa dari Kementerian Desa, Pembangunan Daerah Tertinggal dan Transmigrasi

2. Penetapan Indeks Desa Membangun (IDM) sebagai tolak ukur pembangunan desa

3. Prioritas Dana Desa dari Kementerian Keuangan Indonesia

\section{Faktor Politik}

4. Visi dan Arah Perencanaan Pembangunan Jangka Panjang Nasional tahun 2005-2025 terkait pembangunan kota dan desa

5. Sustainable Development Goals Desa (SDGs Desa)

6. Studi banding antar desa di Indonesia

7. Kerjasama antar desa dalam pembangunan desa

8. Pendampingan digitalisasi desa 
9. Rekomendasi kebijakan IDM

10. Inovasi Desa dan Akademi Desa

11. Program SAMISADE (Satu Miliar Satu Desa)

\section{Efek untuk Desa}

Desa menjadi lebih percaya diri dalam membangun desanya, karena kedudukan desa didukung penuh oleh pemerintah. Pemerintah bahkan memberikan arahan, kebijakan, dan rekomendasi untuk pembangunan desa di Indonesia. Program Inovasi Desa, Akademi Desa, serta kerjasama antar desa, meningkatkan rasa semangat desa untuk melakukan pembangunan yang lebih baik.

\section{Peluang}

1. Pemerintah mendukung dan memfasilitasi pembangunan desa dari mulai kebijakan, arahan, rekomendasi, hingga program yang membantu tercapainya pembangunan desa.

2. Stimulus pemerintah dalam hal dana desa dan bantuan gubernur kepada desa dalam menganggarkan kegiatan yang menunjang pembangunan desa.

3. Tujuan pembangunan yang dituangkan dalam SDGs Desa membantu desa dalam memahami dan melaksanakan pembangunan berkelanjutan.

2. Faktor Ekonomi

Hasil identifikasi faktor ekonomi menunjukkan, terdapat enam faktor ekonomi yang menentukan dan berpengaruh terhadap pelaksanaan pembangunan perdesaan di Indonesia. Kondisi perekonomian dunia mempengaruhi kondisi perekonomian Indonesia, yang juga berpengaruh terhadap penentuan kelancaran pelaksanaan pembangunan di Indonesia. Kondisi perekonomian Indonesia mempengaruhi besaran anggaran dana desa yang dialirkan, keterbatasan anggaran dari pemerintah memberikan tekanan kepada desa dalam melaksanakan pembangunan desa.

Tabel 2. Faktor Ekonomi, Efek, dan Peluang Pembangunan Desa Berkelanjutan

\section{Faktor Ekonomi}

1. Kondisi perekonomian dunia dan Indonesia (PDB, PDRB, Neraca Pembayaran)

2. Potensi ekonomi lokal desa

3. Akses dan modal dalam proses produksi, pengolahan, maupun pemasaran hasil produksi masyarakat desa

4. Kinerja BUMDes

5. UMKM tingkat desa

6. Kemampuan desa memanfaatkan dan memaksimalkan sumber daya 


\section{Efek untuk Desa}

Desa didorong untuk terus berinovasi, dalam meningkatkan ekonomi desa, dan diharuskan untuk memanfaatkan potensi dan sumber daya yang ada.

\section{Peluang}

1. Peningkatan dan penciptaan Pendapatan Asli Daerah (PAD) dari penggalian potensi ekonomi lokal desa dan kinerja BUMDes, serta UMKM yang ada di desa.

2. Tersedianya wadah bagi masyarakat dalam meningkatkan ekonomi masyarakat.

\section{Faktor Sosial}

Faktor sosial yang diidentifikasi berkaitan dengan faktor mental dan sikap sumber daya manusia di desa terhadap lokalitas. Belum optimalnya pemanfaatan potensi ekonomi desa ini disebabkan oleh kesalahan pola pikir masyarakat desa yang masih memandang kawasan perkotaan sebagai tempat yang jauh lebih baik daripada kawasan perdesaan. Cara pandang inilah yang membuat mereka tidak sadar dan mengabaikan potensi desanya.

Tabel 3. Faktor Sosial, Efek, dan Peluang Pembangunan Desa Berkelanjutan

\section{Faktor Sosial}

1. Kesenjangan sosial

2. Struktur masyarakat desa

3. Tingkat pendidikan dan kesehatan

4. Penyediaan lapangan kerja di desa

5. Kondisi keterisolasian

6. Laju Pertumbuhan Penduduk

7. Tingkat angkatan kerja, penduduk yang bekerja, dan pengangguran

8. Agama dan kepercayaan masyarakat desa

9. Pelestarian budaya lokal

10. Tingkat pertumbuhan penduduk migrasi

11. Distribusi gender, usia, dan harapan hidup

12. Sikap dan gaya masyarakat terhadap lingkungan/ekologi

13. Mental berwirausaha

14. Perbedaan upah buruh di kota dan desa 
15. Tinggi Rendahnya integrasi budaya dan adat istiadat

\section{Efek untuk Desa}

Desa diharuskan untuk meningkatkan kualitas sumber daya manusianya, dan mengarahkan masyarakat desa dalam pembangunan desa, khususnya pembangunan yang berkelanjutan. Peningkatan sumber daya manusia dalam bidang pendidikan, ketenagakerjaan, serta sikap dan mental sumber daya manusia itu sendiri.

\section{Peluang}

1. Pemberdayaan masyarakat desa melalui pelatihan-pelatihan yang disediakan.

2 Pelestarian budaya lokal yang dijunjung tinggi oleh masyarakat dan dapat menciptakan Desa Wisata.

4. Faktor Teknologi

Hasil identifikasi menunjukkan bahwa faktor teknologi yang dapat memperlancar pelaksanaan pembangunan pedesaan adalah teknologi dalam penyediaan sarana dan prasarana di desa. Faktor lebih lanjut dapat dilihat pada Tabel 4.

Tabel 4. Faktor Teknologi, Efek, dan Peluang Pembangunan Desa Berkelanjutan

\section{Faktor Teknologi}

1. Perkembangan dan riset teknologi

2. Akses teknologi modern

3. Tingkat infrastruktur dasar

4. Tingkat teknologi di perdesaan

5. Transportasi dan Telekomunikasi

6. Akses listrik dan jaringan

\section{Efek untuk Desa}

Desa memiliki kemudahan dalam menyebarkan informasi, namun juga desa dituntut agar perubahan teknologi dapat berkesinambungan dengan diharuskannya perubahan pola pikir masyarakatnya.

\section{Peluang}

1. Tersedianya pelayanan masyarakat berbasis digital sehingga lebih efisien.

2 Infrastruktur memadai yang menghubungkan beberapa wilayah di desa.

\section{Faktor Ekologi}

Analisis faktor ekologi berkesinambungan dengan tujuan pembangunan berkelanjutan. 
Tujuan dari analisis faktor ekologi dapat membantu mengidentifikasi lingkungan apa saja yang dapat mempengaruhi pembangunan berkelanjutan khususnya di perdesaan. Penjelasan lebih menyeluruh dapat dilihat pada Tabel 4.

Tabel 4. Faktor Ekologi, Efek, dan Peluang Pembangunan Desa Berkelanjutan

\section{Faktor Ekologi}

1. Perubahan iklim

2. Pengelolaan sampah

3. Produk yang ramah lingkungan

4. Penjagaan hutan

5. Penggunaan energi terbarukan

6. Pengurangan penggunaan kantong plastik

\section{Efek untuk Desa}

Desa harus melaksanakan pembangunan yang bersifat menjaga kelestarian lingkungan sekitar.

\section{Peluang}

1. Pengurangan penggunaan kantong plastik membantu pemahaman masyarakat mengenai bahaya sampah plastik, sekaligus melakukan pembangunan berkelanjutan secara bertahap.

2 Menyelenggarakan program dan acara yang mengedukasi masyarakat untuk menggunakan produk yang ramah lingkungan.

6. Faktor Hukum

Faktor hukum terkait pembangunan desa di Indonesia cukup komprehensif, karena basis politik pembangunan desa yang terbentuk sudah kuat. Faktor-faktor hukum yang berkaitan dengan pembangunan desa berkelanjutan, dapat dilihat pada Tabel 6.

Tabel 6. Faktor Hukum, Efek, dan Peluang Pembangunan Desa Berkelanjutan

\section{Faktor Hukum}

1. $\quad$ Peraturan Pemerintah No. 43 Tahun 2014 mengenai Pelaksanaan Undang-Undang No. 6 Tahun 2014 tentang Desa

2. Undang-Undang No. 6 Tahun 2014 tentang Desa

3. Peraturan Pemerintah Nomor 60 Tahun 2014 tentang Dana Desa yang Bersumber dari Anggaran Pendapatan dan Belanja Negara 
4. PERMENDES No. 22 Tahun 2016 tentang penetapan prioritas penggunaan dana desa tahun 2017

5. PERMENDES No. 2 Tahun 2016 tentang Indek Desa Membangun

6. Peraturan Pemerintah No. 43 Tahun 2014 mengenai Pelaksanaan Undang-Undang No. 6 Tahun 2014 tentang Desa

7. PERMENDESA No. 3 Tahun 2015 tentang pendampingan desa

8. PERMENDESA No. 4 Tahun 2015 tentang pendirian, pengurusan, pengelolaan, dan pembubaran Badan Usaha Milik Desa (BUMDes)

9. Peraturan Menteri Dalam Negeri Republik Indonesia Nomor 114 Tahun 2014 tentang pedoman pembangunan desa

10. Peraturan Presiden Nomor 59 Tahun 2017 tentang Pelaksanaan Pencapaian Tujuan Pembangunan Berkelanjutan

11. Permendesa PDTT 13 tahun 2020 tentang prioritas penggunaan dana desa tahun 2021

12. Undang-Undang Nomor 1 Tahun 2020 tentang Kebijakan Keuangan Negara dan Stabilitas Sistem Keuangan untuk Penanganan Pandemi Coronavirus Disease 2019 (COVID-19)

\section{Efek untuk Desa}

Desa didukung dan mempunyai kedudukan secara hukum sehingga desa lebih mudah untuk melaksanakan pembangunan karena jelas fungsi dan kedudukannya.

\section{Peluang}

1. Desa dapat mempercepat pelaksanaan pembangunan desa dengan memanfaatkan kebijakan yang diberikan pemerintah khususnya dana desa.

2 Pembangunan desa sangat terarah dengan adanya payung hukum kebijakan, serta rekomendasi dari pemerintah.

Berdasarkan hasil analisis PESTEL, faktor politik, ekonomi, 153ocial, teknologi, lingkungan/ekologi, dan hukum, memiliki pengaruh atau efek, serta peluang bagi desa di Indonesia. Faktor politik, ekonomi, teknologi, dan hukum, menunjukan bahwa pemerintah Indonesia sangat mendukung pembangunan desa yang berkelanjutan. Namun, dilihat dari faktor 153ocial dan lingkungan/ekologi, belum sepenuhnya mendukung proses pembangunan desa yang berkelanjutan.

\section{Hasil Analisis SOAR}

Analisis SOAR didasarkan pada wawancara dan data sekunder yang diperoleh. Dibagi menjadi dua kelompok komponen: pertama, komponen yang menggambarkan kondisi desa saat ini terdiri dari komponen kekuatan dan komponen peluang; kedua, komponen yang menggambarkan keinginan/harapan desa ke depan terdiri dari komponen aspirasi dan komponen hasil. Berbeda dengan analisis SWOT, Analisis SOAR berfokus pada analisis komponen positif JRIEB is licensed under Creative Commons Attribution- 
desa dalam perumusan strategi yang efektif. Berikut ini penjelasan lebih detail dari hasil analisis masing-masing faktor pada SOAR.

1. Kekuatan dan Peluang

Komponen Kekuatan diperoleh dari wawancara dengan pemerintah desa dan masyarakat desa. Khusus untuk komponen peluang, dibuat dari ekstraksi hasil peluang yang muncul dari hasil analisis PESTEL.Gambaran lebih jelas mengenai komponen kekuatan dan peluang pembangunan desa dapat dilihat pada Tabel 7.

Tabel 7. Komponen Kekuatan dan Peluang

\section{Kekuatan}

1. Kedisiplinan pemerintah desa

2. Perencanaan pembangunan desa

3. Pengembangan BUMDes

4. Kawasan strategis

5. Potensi sumber daya

6. Infrastruktur yang memadai

7. Sarana dan prasarana yang memadai

8. Kegiatan masyarakat yang aktif

9. Kerjasama dengan Lembaga-lembaga desa

10. Transparansi anggaran dan alokasi dana desa

\section{Peluang}

1. Pemerintah mendukung dan memfasilitasi pembangunan desa dari mulai kebijakan, arahan, rekomendasi, hingga program yang membantu tercapainya pembangunan desa.

2 Stimulus pemerintah dalam hal dana desa dan bantuan gubernur kepada desa dalam menganggarkan kegiatan yang menunjang pembangunan desa.

3. Peningkatan dan penciptaan Pendapatan Asli Daerah (PAD) dari penggalian potensi ekonomi lokal desa dan kinerja BUMDes, serta UMKM yang ada di desa.

4. Tersedianya wadah bagi masyarakat dalam meningkatkan ekonomi masyarakat.

5. Pemberdayaan masyarakat desa melalui pelatihan-pelatihan yang disediakan.

6. Pelestarian budaya lokal yang dijunjung tinggi oleh masyarakat dan dapat menciptakan Desa Wisata.

7. Tersedianya pelayanan masyarakat berbasis digital sehingga lebih efisien. 
8. Infrastruktur memadai yang menghubungkan beberapa wilayah di desa.

9. Pengurangan penggunaan kantong plastik membantu pemahaman masyarakat mengenai bahaya sampah plastik, sekaligus melakukan pembangunan berkelanjutan secara bertahap.

10. Menyelenggarakan program dan acara yang mengedukasi masyarakat untuk menggunakan produk yang ramah lingkungan.

11. Desa dapat mempercepat pelaksanaan pembangunan desa dengan memanfaatkan kebijakan yang diberikan pemerintah khususnya dana desa.

12. Pembangunan desa sangat terarah dengan adanya payung hukum kebijakan, serta rekomendasi dari pemerintah.

2. Aspirasi dan Hasil

Komponen aspirasi dan hasil merupakan gambaran harapan dan cita-cita warga desa yang diwawancarai. Berdasarkan hasil wawancara, aspirasi dan hasil pembangunan desa dapat dilihat pada Tabel 8.

Tabel 8. Komponen Aspirasi dan Hasil

\section{Aspirasi}

1. Terbentuknya masyarakat yang mandiri dan makmur secara ekonomi

2. Penuntasan pembangunan jalan warga yang belum terjangkau

3. Meningkatkan kualitas sumber daya manusia

4. Tersedia lapangan pekerjaan bagi pemuda di desa

\section{Hasil}

1. Mampu mempertahankan status pembangunan desa mandiri dan menjadi desa yang berkelanjutan

2 Terbentuknya sumber daya manusia yang handal

3. Memiliki dan menggali Pendapatan Asli Daerah (PAD)

4. Terciptanya Desa Wisata

Berdasarkan hasil analisis PESTEL dan SOAR yang telah uraikan sebelumnya, peneliti dapat menarik empat strategi khusus pembangunan desa: pertama, strategi yang memanfaatkan kekuatan desa untuk mewujudkan aspirasi seluruh masyarakat desa (Strategi StrengthAspirations); kedua, strategi yang memanfaatkan kekuatan desa untuk mewujudkan misi dan visi desa (Strategi Strength-Results); ketiga, strategi yang memanfaatkan peluang yang ada untuk mewujudkan aspirasi seluruh masyarakat pedesaan (Strategi Opportunities-Aspiration); keempat, strategi yang memanfaatkan peluang yang ada untuk mewujudkan visi dan misi desa (Strategi Opportunities-Result). Uraian yang lebih jelas dari keempat strategi tersebut dapat dilihat pada Tabel 9. 
Tabel 9. Strategi Pembangunan Desa Mandiri yang Berkelanjutan

\begin{tabular}{crl}
\hline Matriks SOAR & \multicolumn{1}{c}{ Strategi } \\
\hline $\begin{array}{c}\text { Strength- } \\
\text { Aspirations }\end{array}$ & 2. & $\begin{array}{l}\text { Pemerintah desa membuat sektor usaha yang melibatkan masyarakat } \\
\text { desa setempat melalui BUMDes. } \\
\text { Pemerintah desa membuat program pembentukan karakter bagi } \\
\text { masyarakat desa khususnya pemuda yang belum aktif dalam kegiatan } \\
\text { desa. }\end{array}$ \\
& 3. $\begin{array}{l}\text { Pembangunan infrastruktur desa yang kurang memadai di segala sudut } \\
\text { desa dengan melibatkan desa setempat dalam pembangunannya. }\end{array}$ \\
\hline Strength- Results & 1. $\begin{array}{l}\text { Memanfaatkan potensi desa (danau dan kawasan strategis di Jl. Raya } \\
\text { Jakarta-Bogor) dengan membentuk Desa Wisata yang dikelola oleh } \\
\text { masyarakat desa di bawah arahan pemerintah desa, pemerintah kota, } \\
\text { dan Kementrian Desa sebagai jalan terciptanya PAD desa. }\end{array}$ \\
\hline Opportunities- & 1. $\begin{array}{l}\text { Memberdayakan masyarakat desa secara masif sebagai pelaku penting } \\
\text { dalam meningkatkan pembangunan desa dengan memanfaatkan } \\
\text { fasilitas dari Kemendesa seperti Akademi Desa dan Inovasi Desa. } \\
\text { Pembangunan infrastruktur dan pelaksanaan program kegiatan yang } \\
\text { menunjang pembangunan desa melalui alokasi dana desa. }\end{array}$ \\
\hline Opportunities- & 2. & $\begin{array}{l}\text { Mensosialisasikan dan menerapkan SDGs desa dalam program } \\
\text { kegiatan desa untuk menciptakan desa mandiri yang berkelanjutan. } \\
\text { Renciptakan Desa Wisata melalui alokasi dana desa sebagai wadah } \\
\text { PAD desa } \\
\text { Bekerjasama dengan Kementrian Desa untuk mengadakan program } \\
\text { peningkatan kualitas sumber daya manusia yang menerapkan aspek } \\
\text { pembangunan berkelanjutan. }\end{array}$ \\
\hline
\end{tabular}

\section{Kesimpulan}

Berdasarkan pembahasan dalam penelitian ini, peneliti menyimpulkan beberapa hasil penelitian sebagai berikut:

1. Terdapat sembilan strategi percepatan pembangunan Desa Mandiri yang berkelanjutan. Strategi S-A memiliki tiga strategi yang berfokus pada bidang ekonomi, sosial, dan infrastruktur desa. Strategi S-R memiliki satu strategi yang memanfaatkan potensi desa (kekuatan yang dimiliki desa) untuk menciptakan desa wisata dan PAD Desa Pondok Udik. Strategi S-R tidak hanya berfokus pada bidang ekonomi desa, tetapi juga memperhatikan aspek sosial, ketenagakerjaan, infrastruktur, dan tata kelola desa. Strategi O-A memiliki dua strategi yang berfokus pada bidang sosial masyarakat desa, infrastruktur desa, dengan memanfaatkan fasilitas yang diperoleh melalui Kemendesa seperti dana desa, Akademi Desa, dan Inovasi Desa. Kemudian strategi O-R memiliki tiga strategi, berfokus pada pembangunan desa berkelanjutan yang melibatkan semua aspek baik itu pemerintah desa, masyarakat desa, hingga Kemendesa.

2. Berdasarkan kesimpulan yang diperoleh, maka terdapat saran bagi Desa Berkembang yang ada di Indonesia, dengan menjadikan strategi Desa Pondok Udik sebagai contoh keberhasilan pembangunan Desa Mandiri. Pertama, strategi yang memanfaatkan kekuatan desa untuk mewujudkan aspirasi seluruh masyarakat desa setempat. Kedua, strategi yang memanfaatkan kekuatan desa untuk mewujudkan visi dan misi desa. Kedita, strategi yang memanfaatkan peluang yang ada untuk mewujudkan aspirasi seluruh masyarakat desa. Keempat, strategi yang memanfaatkan peluang yang ada untuk mewujudkan visi dan misi desa. 
3. Berangkat dari keterbatasan dalam penelitian ini hanya meneliti dan mengambil satu studi kasus Desa Mandiri yang ada di Indonesia, dengan mengandalkan satu budaya dan lingkungan desa. Maka dari itu, saran untuk peneliti selanjutnya, diharapkan untuk mengkaji desa-desa mandiri lainnya yang ada di Indonesia, serta desa-desa yang ada di luar Indonesia. Dengan tidak mengandalkan dari satu wilayah dan budaya, tetapi dari berbagai macam wilayah dan budaya. Guna mendapatkan khazanah dan menghasilkan strategi terbaik, yang bisa diaplikasikan kepada desa-desa berkembang yang ada di Indonesia..

\section{Acknowledge}

Terima kasih kepada pihak-pihak yang terlibat dalam penelitian ini. Terima kasih juga kepada Program Studi Ekonomi Pembangunan, Fakultas Ekonomi dan Bisnis, dan Universitas Islam Bandung..

\section{Daftar Pustaka}

[1] Akgün, A., Leeuwen, E. Van, \& Nijkamp, P. (2011). The Usefulness Of Analytical Tools For Sustainable Futures. ERSA Conference Papers, 1-20. Retrieved from http://ideas.repec.org/p/wiw/wiwrsa/ersa11p1575.html

[2] Altieri, M. A., \& Masera, O. (1993). Sustainable Rural Development in Latin America: Building from the Bottom-Up. Ecological Economics, 7, 93-121.

[3] Bappenas. (2019). Rancangan Teknokratik Rencana Pembangunan Jangka Menengah Nasional. In Rencana Pembangunan Jangka Menengah Nasional 2020-2024.

[4] Budiarto, T., Rustiadi, E., \& Dharmawan, A. H. (2017). Perkembangan dan kemandirian desa di Kabupaten Bogor, Provinsi Jawa Barat. Tata Loka, 19(3), 230-241.

[5] Global Food Policy Report. (2019). Crises in Rural Areas Threatens Progress in Hunger, Poverty Reduction; Urgent Need for Rural Revitalization, Strong Policies and Accountability. https://doi.org/10.2499/9780896293502

[6] Hall, P., \& Pfeiffer, U. (2000). Urban Future 21: A Global Agenda for Twenty-First Century Cities. ( $1^{\text {st }}$ Edition). Routledge. https://doi.org/10.4324/9781315011523

[7] Indonesia, R. (2014). Undang-undang Nomor 6 Tahun 2014 tentang Desa.

[8] Kemendesa. (2021). Pusat Data Desa Indonesia Dashboard. Retrieved July 30, 2021, from https://pddi.kemendesa.go.id/

[9] Mihai, F-C., \& Iatu, C. (2020). Sustainable Rural Development under Agenda 2030, Sustainability Assessment at the 21 st century. IntechOpen, DOI: 10.5772/intechopen.90161. Available from: https://www.intechopen.com/chapters/69950

[10] Nurkholis, A. (2018). Teori Pembangunan Sumber daya Manusia: Human Capital Theory, Human Investment Theory, Human Development Theory, Sustainable Development Theory, People Centered Development Theory. 1-16. https://doi.org/10.31227/osf.io/8trv7

[11] Rahmat, A., Izzudin, A., \& Kudir, S. (2015). Menguatkan Pembangunan Desa Berkelanjutan: Perspektif Implementasi UU Desa No. 6 Tahun 2014 di Kabupaten Bantul. Jurnal Kesejahteraan Sosial, 2(02). http://digilib.uin-suka.ac.id/id/eprint/40082

[12] Rusu, R. C. V., Neculită, M., Cristea, D., Mogodan, A., Petrea, Ș, \& Simionov, I. (2020). Sustainable Development of Rural Areas of the South-East Region of Romania. Economic Engineering in Agriculture and Rural Development, 20(2), 523-529.

[13] Scoones, I. (2009). Livelihood's perspectives and rural development livelihoods perspectives and rural development. The Journal of Pasant Studies, 36(1): 171- 196. https://doi.org/10.1080/03066150902820503

[14] Sujito, A., \& Latifah, D. A. (2020). Naskah Input Kebijakan Penguatan Isu Desa dan Kawasan Perdesaan dalam Dokumen Rancangan Teknokratik RPJMD Kabupaten Gunungkidul Tahun 2021-2024. Institute for Research and Empowerment.

[15] Todaro, M. P., \& Smith, S. C. (2012). Economic Development. 